\title{
Muscle Cortisol Levels, Expression of Glucocorticoid Receptor and Oxidative Stress Markers in the Teleost Fish Argyrosomus regius Exposed to Transport Stress
}

\author{
Martina Bortoletti ${ }^{1,+}+\mathbb{C}$, Lisa Maccatrozzo ${ }^{1,+}$, Giuseppe Radaelli ${ }^{1, *}$, Stefano Caberlotto ${ }^{2}$ and Daniela Bertotto ${ }^{1}(\mathbb{D}$ \\ 1 Department of Comparative Biomedicine and Food Science (BCA), University of Padova, \\ I-35122 Padova, Italy; martina.bortoletti@phd.unipd.it (M.B.); lisa.maccatrozzo@unipd.it (L.M.); \\ daniela.bertotto@unipd.it (D.B.) \\ 2 Valle Cà Zuliani Società Agricola Srl, Rovigo, Via Pila 48, I-45018 Pila di Porto Tolle, Italy; \\ stefano.caberlotto@vallecazuliani.it \\ * Correspondence: giuseppe.radaelli@unipd.it; Tel.: +39-049-8272593 \\ + Equal contribution of the first and second author.
}

Citation: Bortoletti, M.; Maccatrozzo, L.; Radaelli, G.; Caberlotto, S.; Bertotto, D. Muscle Cortisol Levels, Expression of Glucocorticoid Receptor and Oxidative Stress Markers in the Teleost Fish Argyrosomus regius Exposed to Transport Stress. Animals 2021, 11, 1160. https://doi.org/10.3390/ ani11041160

Academic Editors: Luciana Castaldo, Carla Lucini and Zoltan M. Varga

Received: 16 March 2021

Accepted: 16 April 2021

Published: 18 April 2021

Publisher's Note: MDPI stays neutral with regard to jurisdictional claims in published maps and institutional affiliations.

Copyright: (c) 2021 by the authors. Licensee MDPI, Basel, Switzerland. This article is an open access article distributed under the terms and conditions of the Creative Commons Attribution (CC BY) license (https:/ / creativecommons.org/licenses/by/ $4.0 /)$.
Simple Summary: Over the years, increasing attention has been given to welfare of farmed animals, but with a focus on mammalian species. Nevertheless, even non-mammalian ones deserve to be considered and especially fish. Aquaculture, in fact, is a globally and rapidly growing industry, since a large variety of fish is consumed every day as an essential source of protein and healthy lipids for human nutrition. However, in common aquaculture practices, such as transportation, fish are exposed to a whole range of potentially adverse stimuli which may substantially influence the welfare of the fish. On this basis, the present study aimed to assess the welfare status of meagre juveniles subjected to a $48 \mathrm{~h}$ transport. For this purpose, stress response in terms of cortisol levels, glucocorticoid receptor and oxidative stress markers' expression has been evaluated. Results revealed that fish were stressed during loading on the truck and within $16 \mathrm{~h}$ from departure and did not fully recover even at the end of the transport. This work highlights how the procedures prior to transport, in particular, loading, may represent a potential welfare concern rather than transport itself. However, it remains essential to follow live animal commercial transportation directions in order to protect animal health and welfare during transport.

Abstract: Fish commercial transport is an ordinary practice in the aquaculture industry. This study aimed to investigate the effect of a $48 \mathrm{~h}$ transport stress on stress response of meagre (Argyrosomus regius) juveniles. Radioimmunoassay (RIA) and Real-Time PCR were used to evaluate muscle cortisol levels and to assess glucocorticoid receptor $(g r)$ gene expression in fish muscle and liver, respectively. Presence and localization of various oxidative stress markers were investigated in different tissues by immunohistochemistry. A significant increase in muscle cortisol levels was observed after loading but a significant decrease occurred after $16 \mathrm{~h}$ from departure even without returning to control levels. Molecular analysis on stress response revealed an increase in muscle $g r$ expression after fish loading that started decreasing during the travel returning to the control level at the end of the transport. Instead, no differences in liver $g r$ expression were observed along the different sampling points. Immunostaining for heat shock protein 70 (HSP70), 4-hydroxy-2-nonenal (HNE), nitrotyrosine (NT) and 8-hydroxy-2'-deoxyguanosine (8-OHdG) antibodies was detected in several organs. Notably, a higher NT immunostaining intensity was evident in skin and gills of the transported animals with respect to controls. Results demonstrated that cortisol and $g r$ are useful indicators of stressful conditions in transported fish.

Keywords: fish transport; cortisol; gr; HSP70; oxidative stress markers; meagre; animal welfare 


\section{Introduction}

During the last years, great attention has been directed towards the improvement of farmed animals' welfare, including fish. Transportation of live fish is a common practice that includes a complex of factors such as handling, air exposure, constraint and low oxygen levels. All these factors are known to induce a stress response in fish, increasing their metabolic rate and overexertion, coupled with a rapid deterioration of water quality. Therefore, given the paramount role that transportation plays in the welfare of farmed fish, several institutions and organizations, both at national (Italian Ministry of Health) and international (European Food Safety Authority and World Animal Health Organization) level, designated specific guidelines providing the best procedures available to ensure fish welfare during transport [1-3].

The overall effect of stress is the activation of the hypothalamic-pituitary-interrenal axis (HPI) and the release of catecholamines and glucocorticoids. In teleosts, cortisol is the primary glucocorticoid that is released in response to stressor activation of the hypothalamus-pituitary-interrenal axis. Cortisol induces secondary responses related mainly to energy requirements and it represents one of the most important stress indicators in fish. The target tissue action of this hormone is primarily mediated by the intracellular glucocorticoid receptor (GR), a ligand-bound transcription factor [4]. Among the different organs, liver and muscle are probably the sites of choice for evaluating its gene expression as they are directly and strongly involved in protein catabolism and gluconeogenesis. Amino acids released from the catabolic effects of GR-mediated cortisol signaling on skeletal muscle tissue are mobilized to liver, where they will be used as substrates for hepatic gluconeogenesis [5-8]. In teleosts, glucocorticoid synthesis takes place in the head kidney interrenal tissue and it is mediated by steroidogenic enzymes [9]. Glucocorticoids play important roles in the homeostasis of many biological systems, including stress response $[10,11]$.

At the cellular level, the formation of reactive oxygen species (ROS) often derives from a stress event [12]. These products are biologically generated during metabolism although in stress conditions, their synthesis is greater than the ability of cells to remove them, leading to lipid peroxidation, protein carbonils' formation, DNA damage and cell death $[13,14]$. One of the most important ROS is the superoxide radical, which reacts with nitric oxide giving rise to peroxynitrite, a potent oxidant that may oxidize proteins, lipids and DNA. Nitrotyrosine (NT) is a relatively stable marker for peroxynitrite production [15].

Lipid peroxides are unstable indicators of oxidative stress in cells that decompose to form more complex and reactive compounds such as 4-hydroxy-2-nonenal (HNE), which is a natural by-product of lipid peroxidation. HNE, the most abundant and toxic $\alpha, \beta$ unsaturated aldehyde, originates from the $\beta$-cleavage of hydroperoxides from $\omega$ - 6 PUFAs and is mainly involved in the inhibition of protein and DNA synthesis, in the inactivation of enzymes, and is also a potent mutagen agent [16]. 8-hydroxy-2'-deoxyguanosine (8$\mathrm{OHdG}$ ), a product of deoxyguanosine oxidation, is an example of DNA damage due to bases' modification [17]. 8-OHdG level as biomarker of DNA damage has been applied in assessing content of DNA damage as it is a major product of oxidative DNA damage with clear mutagenic potential for $\mathrm{G}$ to $\mathrm{T}$ transversions [18].

In a previous work, the distribution of inducible Heat Shock Protein 70 (HSP70), which is expressed in response to stressful stimuli, has been detected in different tissues of sea bass (Dicentrarchus labrax) subjected to transport stress [19]; moreover, in Cyprinus carpio, the inducible form (HSP70) has been localized in the epithelia of renal tubules, gills and skin of animals subjected to transport stress [20].

The aim of the present study was to investigate the muscle cortisol levels, the expression of glucocorticoid receptor in muscle and liver and the cellular distribution of HSP70, HNE, NT and 8-OHdG in several tissues by immunohistochemical approach in the teleost fish meagre (Argyrosomus regius) exposed to commercial transport. 


\section{Materials and Methods}

All procedures and animal care were in compliance with Council Regulation (EC) no. $1 / 2005$ on the protection of animals during transport and Directive (EC) 86/609/EEC on the protection of animals used for experimental and other scientific purposes.

\subsection{Travel Condition from Fish Hatchery and Sampling}

Fish transport has been carried out from Monfalcone (Gorizia, Italy) to Ajaccio (Corsica) by a commercial truck and lasted $48 \mathrm{~h}$. Tanks $\left(2.7 \mathrm{~m}^{3}\right)$ were insulated and provided with aeration and temperature control. Meagre juveniles' weight was $8 \mathrm{~g}$ and density in tanks was kept at $20 \mathrm{~kg} / \mathrm{m}^{3} ; 72 \mathrm{~h}$ fasting period was performed. During the transport, temperature and oxygen levels were respectively $19-23^{\circ} \mathrm{C}$ and $16-22 \mathrm{ppm}$.

Fish were sampled before (control) and after loading that lasted two hours and during and at the end of transport event ( 16 and $48 \mathrm{~h}$ after departure). For each sampling point, 35 fish have been sacrificed with MS222 excess ( $1 \mathrm{~g} / \mathrm{L}$ Sandoz, Milan, Italy).

For cortisol measurement, muscle from 20 fish was collected from the caudal peduncle and immediately frozen and kept in dry ice. For biomolecular analysis, muscle and liver samples from 10 fish were collected and immersed in RNA later (Life Technologies, Carlsbad, CA, USA) and stored at $20^{\circ} \mathrm{C}$ until analysis. For immunohistochemistry, several organs (gills, oropharyngeal cavity, stomach, intestine, liver, pancreas, lateral muscle, and skin) from 5 fish were fixed in paraformaldehyde in phosphate buffer saline (PBS, $0.1 \mathrm{M}$, $\mathrm{pH}$ 7.4) at $4{ }^{\circ} \mathrm{C}$ overnight, PBS washed, dehydrated and embedded in paraffin. Serial sections of $4 \mu \mathrm{M}$ were obtained using a microtome.

\subsection{Cortisol Measurement}

Cortisol was measured with a microtiter RIA, as described by Bertotto et al. [21], validated for the meagre, after extraction of $100 \mathrm{mg}$ of muscle in diethyl ether. The sensitivity of the assay was $3.125 \mathrm{pg}$ well $^{-1}$.

\subsection{RNA Extraction and Real-Time PCR}

Qualitative reverse transcription/PCR and quantitative Real-Time PCR were performed by following the methods detailed in Bertotto et al. [22]. Total RNA was extracted from muscle and liver dissected from fish at different times during transportation (10 animals for each sampling point): 1 . at the fish hatchery, before transport; 2 . just loaded on the truck; 3 . during transport; 4 . at the end of transportation, using TRIZOL reagent (Life Technologies, Carlsbad, CA, USA) following the manufacturer's protocol.

PCRs were performed in triplicate in a Real-Time PCR 7500 thermal cycler (Applied Biosystems, by Life Technologies). Specific primers for Glucocorticoid receptor gene (forward $5^{\prime}$-GCCTTTTGGCATGTACTCAAACC- $3^{\prime}$ and reverse $5^{\prime}$-GGACGACTCTCCATACCT GTTC- $3^{\prime}$ ) and for $\beta$-actin (forward $5^{\prime}$-ACCCTGTCCTGCTCACAGAG- $3^{\prime}$ and reverse $5^{\prime}$ GGGAGTCCATAACAATACCAGTG-3') used as reference gene, were designed with Primer Express software version 3.0 (Applied Biosystems, Life Technologies).

Relative quantification of the expression of glucocorticoid receptor gene was performed using $\beta$-actin as the housekeeping genes to standardize results.

\subsection{Immunohistochemistry (IHC)}

All the antibodies used in this study are reported in Table 1. Immunohistochemical staining was performed using the Elite ABC KIT system (Vector Laboratories, Inc., Burlingame, CA, USA) as described in Pascoli et al. [23]. Briefly, after endogenous peroxidase activity and non-specific binding sites were blocked, sections were incubated with primary antibodies (see Table 1), at $4{ }^{\circ} \mathrm{C}$ overnight. After PBS washing, sections were incubated with anti-rabbit or Ig antibodies, biotin-conjugated anti-mouse (Dakocytomation), PBS washed and reacted with peroxidase-labeled avidin-biotin complex (Vector Laboratories, Inc., Burlingame, CA, USA). The immunoreactive sites were visualized using 3.3'-diaminobenzidine tetrahydrochloride (DAB, Sigma, Milan, Italy). To detect structural 
details, sections were counterstained with Mayer's haematoxylin. Immunostaining specificity was validated by incubating sections with: (i) PBS instead of the specific primary antibodies (see Table 1); (ii) preimmune sera instead of the primary antisera; (iii) PBS instead of the secondary antibodies. The results of these controls were negative (i.e., staining was abolished).

Table 1. Primary antibodies used.

\begin{tabular}{|c|c|c|c|c|c|}
\hline Target Protein & Antibody & Species & Dilution & Characterization & Immunizing Antigen/Source \\
\hline $\begin{array}{l}\text { Heat Shock Protein } 70 \\
\text { (HSP70) }\end{array}$ & Anti-HSP70 & mouse monoclonal & 1:600 (IHC) & Immunohistochemistry & $\begin{array}{c}\text { Recombinant fragment from human } \\
\text { Hsp70 (Abcam, UK) }\end{array}$ \\
\hline 4-hydroxy-2-nonenal (HNE) & Anti-HNE & mouse monoclonal & 1:50 (IHC) & Immunohistochemistry & $\begin{array}{c}\text { 4-hydroxy-2-nonenal modified } \\
\text { KLH (Abcam, UK) } \\
\text { 3-(4-hydroxy-3- }\end{array}$ \\
\hline Nitrotyrosine (NT) & Anti-NT & mouse monoclonal & 1:1000 (IHC) & Immunohistochemistry & $\begin{array}{l}\text { nitrophenylacetamido) propionic } \\
\text { acid conjugated to bovine serum } \\
\text { albumin (BSA) (GeneTex, Inc., USA) }\end{array}$ \\
\hline $\begin{array}{l}8 \text { Hydroxy-2'-guanosine } \\
\text { (8-OHdG) }\end{array}$ & Anti-8-OHdG & mouse monoclonal & 1:3000 (IHC) & Immunohistochemistry & $\begin{array}{l}\text { 8-Hydroxy-2'-deoxyguanosine } \\
\text { conjugated Keyhole Limpet } \\
\text { Hemocyanin (Abcam, UK) }\end{array}$ \\
\hline
\end{tabular}

\subsection{Statistical Analysis}

Statistical analysis was carried out by means of STATISTICA 8.0 (StatSoft, Tulsa, OK, USA). The cortisol concentration values, in the different transport phases, were previously transformed using a logarithmic function and then compared by means of one-way analysis of variance (ANOVA); in the presence of significant differences between the means, a post hoc comparison of Honestly Significant Difference (HSD) for unbalanced designs was carried out.

The analysis of Real-Time PCR data on the presence of the mRNA for the glucocorticoid receptor (GR), both in the muscle and in the liver and in the various stages of transport, was carried out using the GLM (General Linear Model) approach; also, in this case, the data were transformed with a logarithmic function.

\section{Results}

\subsection{Cortisol Measurement}

The cortisol assay showed acceptable parallelism and reproducibility (linear regression curve $y=11.2 x+0.1$; regression coefficient $R^{2}: 0.99 ; C V \%$ intra-assay $\left.=1.7\right)$. The recovery test with value higher than $86 \%$ confirmed the efficiency of steroid extraction method. Muscle cortisol increased in fish after loading $(p<0.0001)$ but a significant decrease occurred soon after $16 \mathrm{~h}$ from departure even without returning to the control levels (Figure 1).

\subsection{RNA Expression}

Relative quantification of glucocorticoid receptor gene reveals an increase in muscle after fish loading $(p<0.001)$ that has been maintained after $16 \mathrm{~h}$ from departure but decreased returning to the control level at the end of the transport (Figure 2). No differences in expression of glucocorticoid receptor in the different sampling points were detected in the liver $(p=0.4)$.

\subsection{HSP70 Immunohistochemistry}

Immunoreactivity to HSP70 antibody was detected in several tissues and organs although no differences were found between control and stressed animals (Table 2).

In particular, at cellular level, immunoreactivity to HSP70 antibody was detected in: (i) hepatocytes of liver parenchyma (Figure 3A, insert in A); (ii) cells lining the gastric glands of the stomach (Figure 3B); (iii) cells of gill epithelium at the level of filaments and lamellae (Figure 3C); (iv) the muscle fibre of skeletal lateral muscle (Figure 3D). Immunoreactivity was also present in the epithelia of skin and intestine (Table 2). 


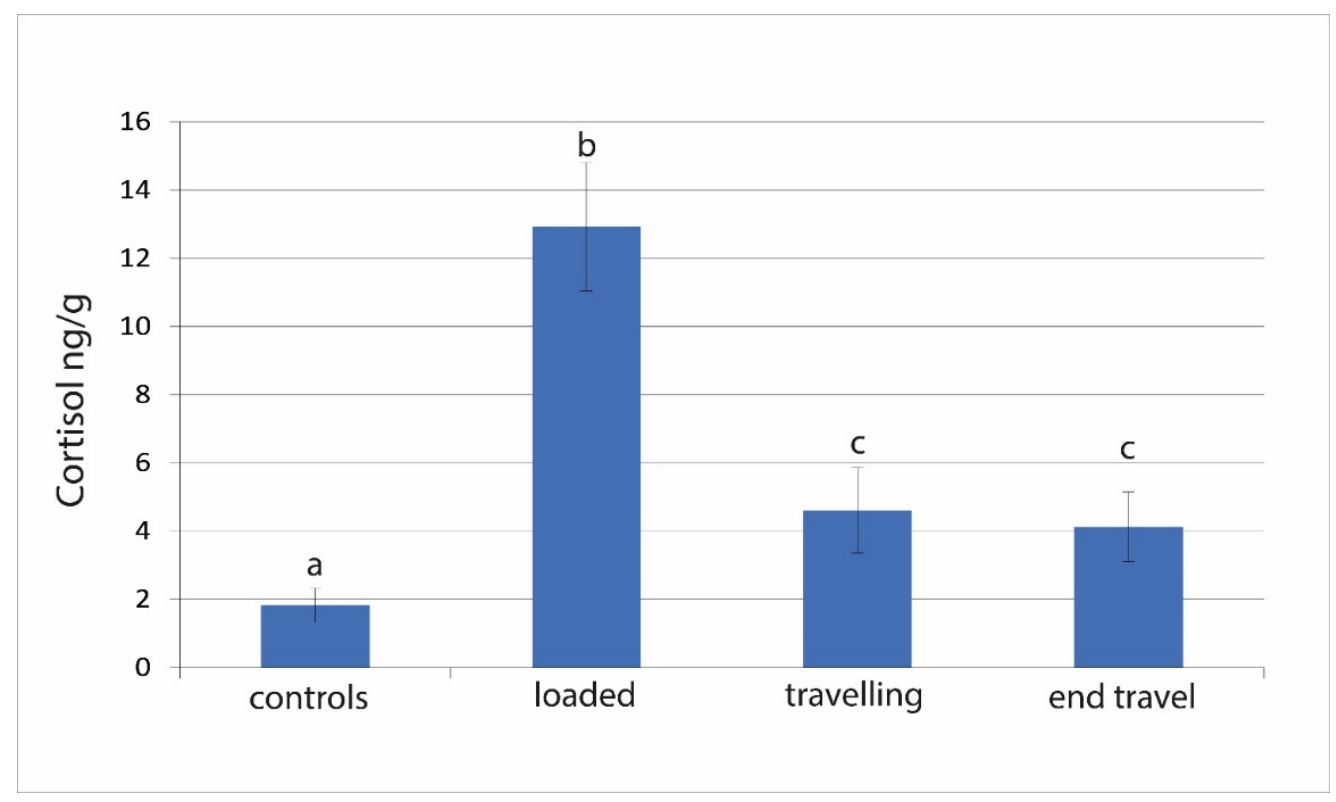

Figure 1. Cortisol concentrations detected in meagre muscle at four steps: at the fish farm, before transport; just loaded on the truck; during transport; at the end of transportation. Data are expressed as mean \pm standard error (SE) $(n=20)$. a, b, c: Different letters denote statistically significant differences at the different sampling points $(p<0.0001)$.

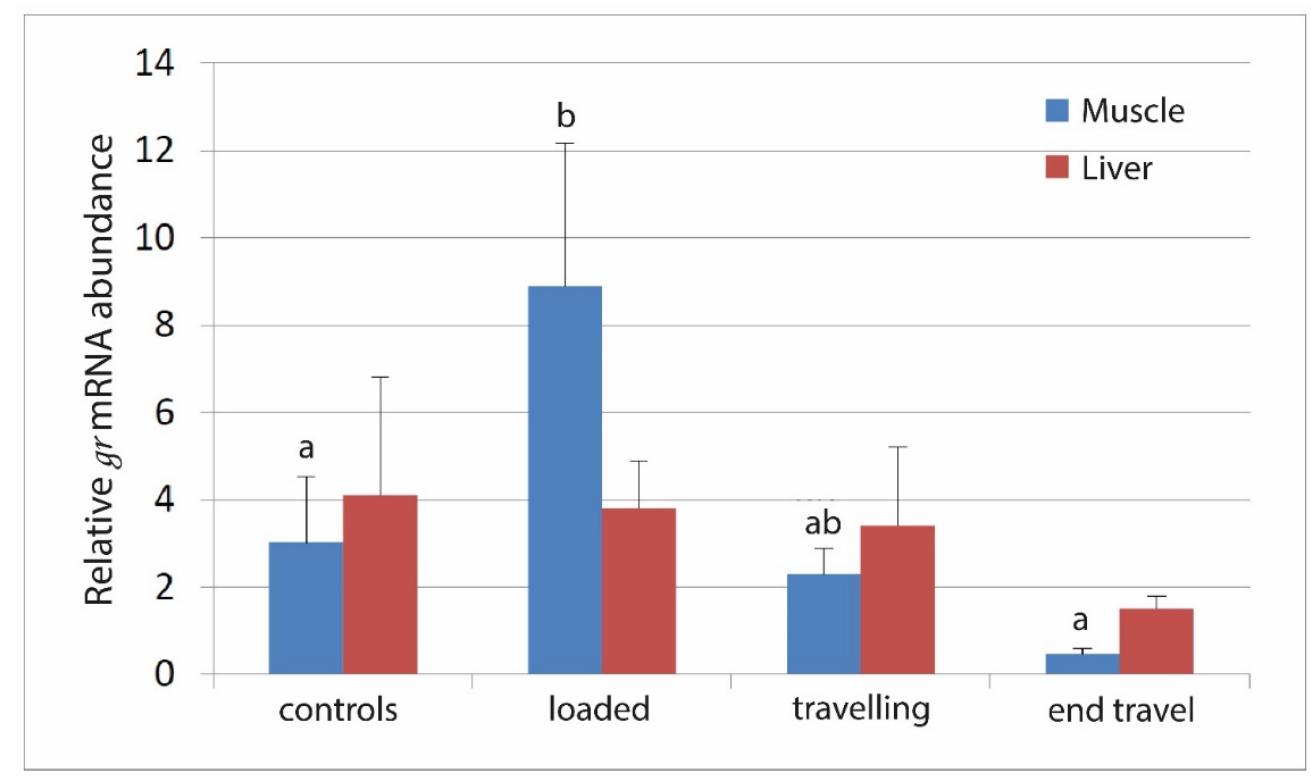

Figure 2. Relative expression of glucocorticoid receptor mRNA detected in meagre muscle and liver. Real-Time PCR levels were calculated at four steps: at the fish farm, before transport; just loaded on the truck; during transport; at the end of transportation. Values are means \pm standard error (SE) $(n=10)$. a, b: Different letters denote statistically significant differences at the different sampling points, while the absence of letters indicates absence of significant differences. 
Table 2. Immunohistochemical localization of heat shock protein 70 (HSP70), 4-hydroxy-2-nonenal (HNE), nitrotyrosine (NT) and 8-hydroxy-2'-deoxyguanosine (8-OHdG) in different tissues of meagre (transported and control animals): - , not detectable; $+/-$, slight but above background levels; + , moderate staining; ++ , marked staining.

\begin{tabular}{|c|c|c|c|c|c|c|c|c|}
\hline \multirow{2}{*}{ Tissue } & \multicolumn{4}{|c|}{ CTRL } & \multicolumn{4}{|c|}{ Transport Stress (End Travel) } \\
\hline & HSP70 & HNE & NT & 8-OHdG & HSP70 & HNE & NT & 8-OHdG \\
\hline Skin & + & + & + & + & + & + & ++ & + \\
\hline $\begin{array}{c}\text { Oropharyngeal } \\
\text { cavity }\end{array}$ & $+1-$ & ++ & $+/-$ & $+1-$ & $+1-$ & ++ & $+/-$ & $+/-$ \\
\hline Stomach & ++ & + & $+/-$ & ++ & ++ & + & + & ++ \\
\hline Intestine & + & ++ & + & + & + & ++ & + & + \\
\hline Liver and pancreas & ++ & + & + & + & ++ & + & + & + \\
\hline Gills & ++ & ++ & + & ++ & ++ & ++ & ++ & ++ \\
\hline Muscle & ++ & + & $+1-$ & - & ++ & + & + & $+1-$ \\
\hline
\end{tabular}
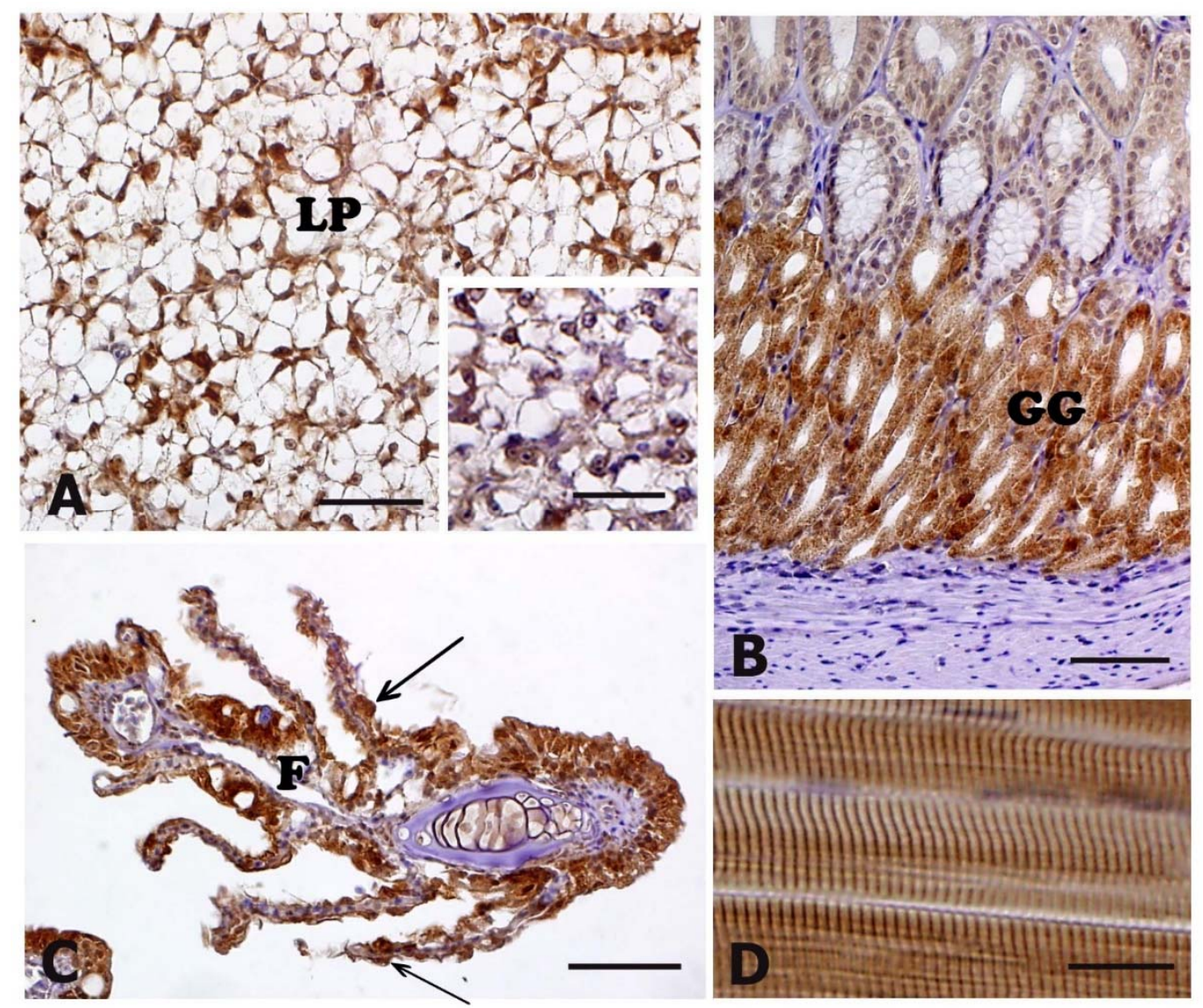

Figure 3. Heat shock protein 70 (HSP70) immunohistochemical localization in meagre (Argyrosomus regius). Panel (A) represents a control animal; insert in (A) and panels (B-D) represent animals exposed to transport stress. All panels are counterstained with Mayer's haematoxylin. No differences in term of immunoreactivity were observed between control and transported animals (see also Table 2). (A) In liver, HSP70-immunostaining is present in the parenchyma (LP), at the level of the cytoplasm of hepatocytes. (B) In the stomach, immunopositivity is present in the gastric glands (GG). (C) The epithelial cells lining both filaments (F) and lamellae (arrows) show a marked HSP-70 immunoreactivity. (D) In skeletal lateral muscle, fibers exhibit a marked immunopositivity. Scale bars: (A-C) $20 \mu \mathrm{M}$; (D) $10 \mu \mathrm{M}$; insert in (A) $20 \mu \mathrm{M}$.

\subsection{HNE Immunohistochemistry}

Positive immunostaining of the anti-HNE antibody was exhibited in the oropharyngeal cavity, stomach, liver, intestine, and skin, although no differences were detectable 
between control and stressed animals (Table 2). In the oropharyngeal cavity, HNEimmunostaining was visible in the cytoplasm of the epithelial cells of the mucosa (Figure 4A). In the stomach, the cytoplasm of cells lining the gastric glands exhibited a moderate HNE-immunostaining (Figure 4B, insert in B). In the liver, immunostaining was diffusely detectable in the cytoplasm of hepatocytes (Figure 4C). In the intestine, an evident HNEimmunostaining was visible in the cytoplasm of enterocytes (Figure 4D).

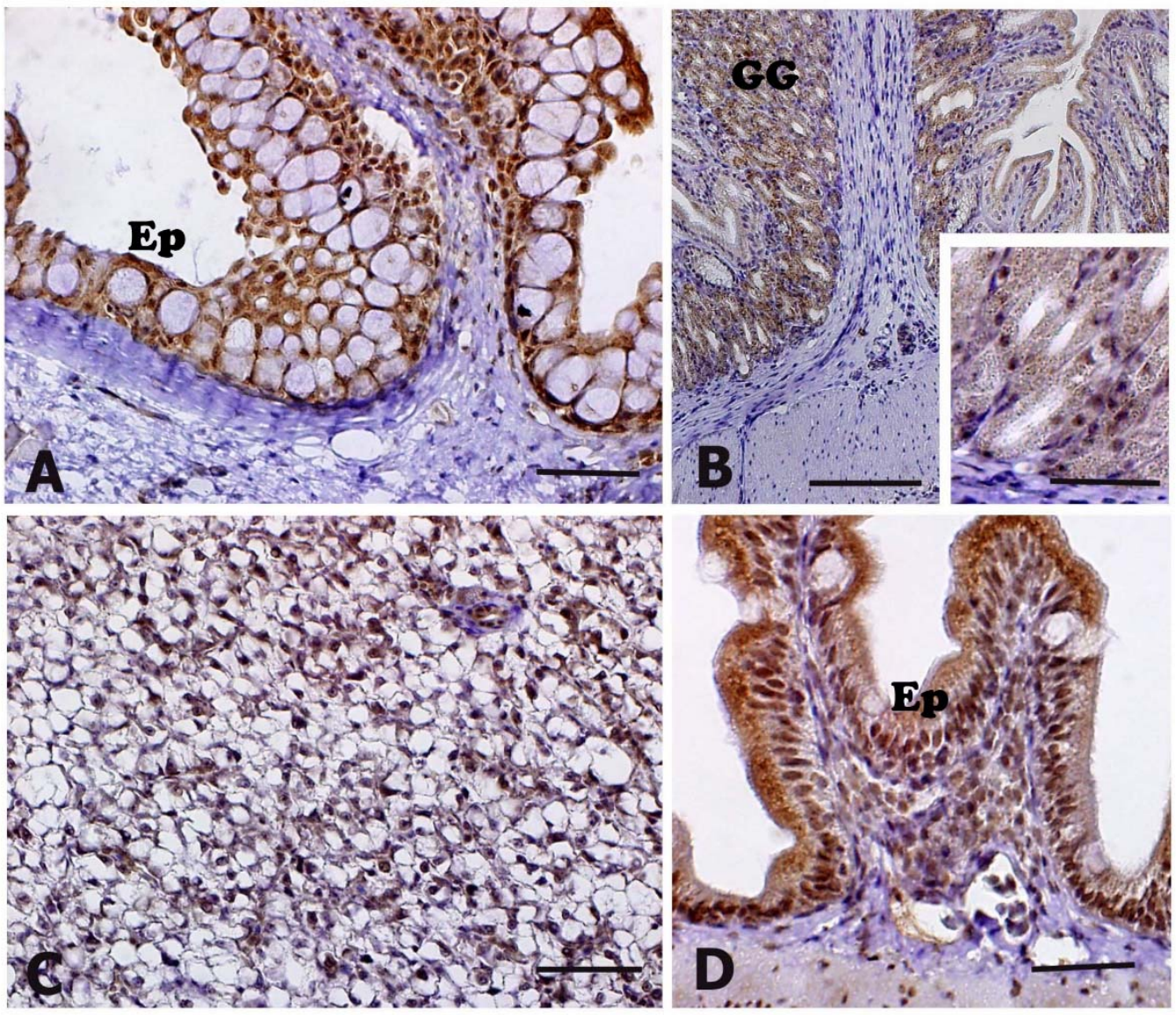

Figure 4. 4-hydroxy-2-nonenal (HNE) immunohistochemical localization in meagre (Argyrosomus regius). Panels (A), (B) and (D) represent animals exposed to transport stress, whereas panel (C) and the insert in (B) represent a control animal. No differences in term of immunoreactivity were observed between control and transported animals (see also Table 2). All panels are counterstained with Mayer's haematoxylin. (A) The epithelium (Ep) of the oropharyngeal cavity exhibits a marked HNE-immunostaining. (B) In the stomach, a moderate HNE positivity is detectable in gastric glands (GG), although no differences in terms of reactivity were visible between control (insert in (B)) and stressed animals (B). (C) Liver of an animal from the control group, which exhibits immunostaining in the cytoplasm of hepatocytes. (D) In the intestine, a marked HNE immunopositivity was visible in the cytoplasm of enterocytes (Ep). Scale bars: (A-D) $20 \mu \mathrm{M}$, insert in (A) $20 \mu \mathrm{M}$.

\subsection{NT and 8-OHdG Immunohistochemistry}

The anti-NT antibody exhibited positivity (Table 2) in the epithelial cells of skin (Figure 5A), in the cytoplasm of hepatocytes, as well as in the pancreatic glands (Figure 5B). Moreover, immunopositivity was evident in the enterocytes of the intestinal mucosa (Figure 5C) and in the epithelial cells lining both filaments and lamellae of gills (Figure 5D). The immunostaining intensity observed in skin and gills of stressed animals was higher than that observed in controls (Table 2). In other tissues, no differences were detectable between control and stressed animals (Table 2). 


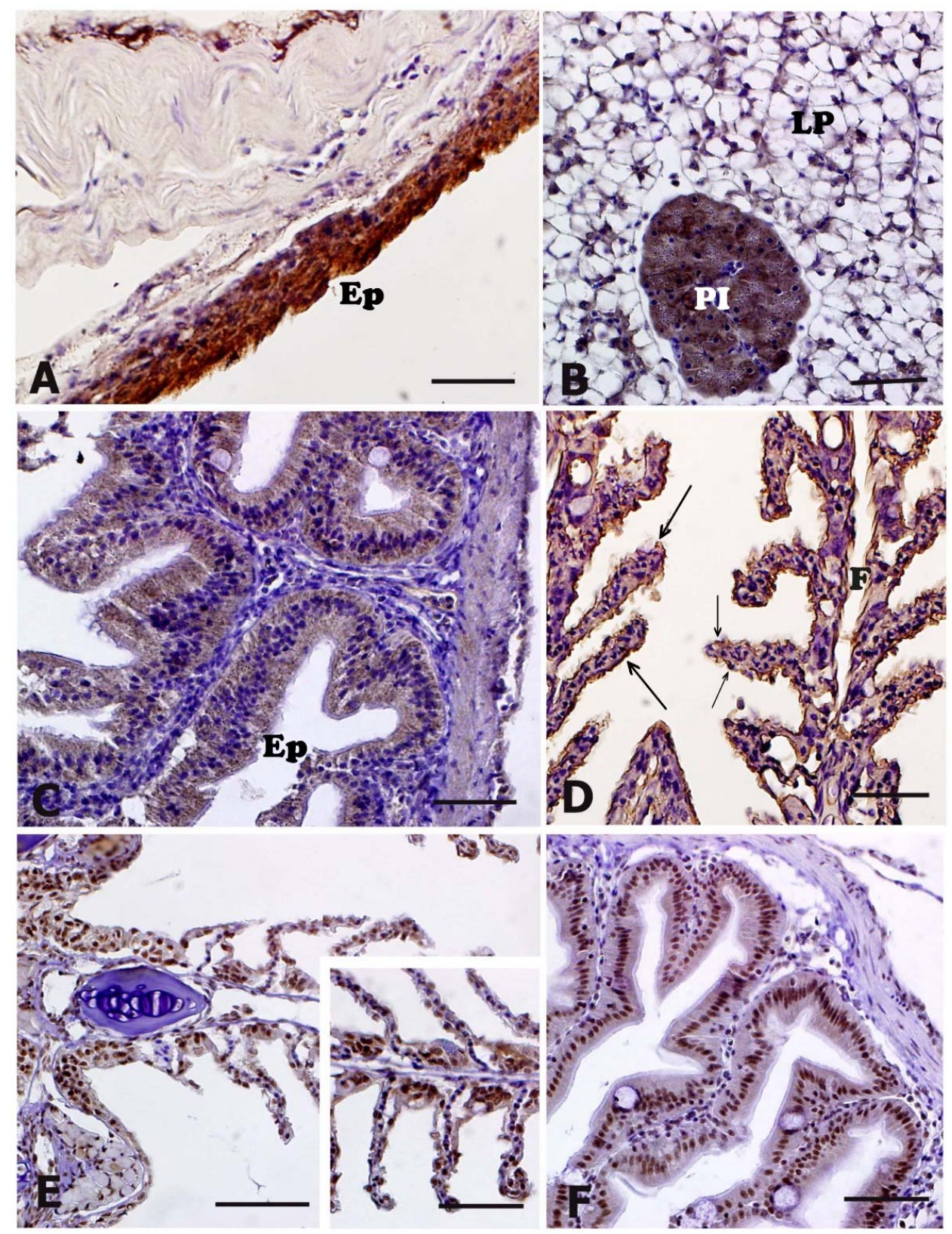

Figure 5. Nitrotyrosine (NT) in panels (A-D) and 8-hydroxy-2'-deoxyguanosine (8-OHdG) in panels (E,F) immunohistochemical localization in meagre (Argyrosomus regius). All panels are counterstained with Mayer's haematoxylin and represent animals exposed to transport stress. Insert in (E) represents a control animal. (A) Skin of stressed animals which exhibits a marked NT immunopositivity in the epithelium (Ep). (B) Liver and pancreas of a stressed animal showing NT-immunostaining in both hepatocytes of the liver parenchyma (LP) and pancreatic islands (PI). (C) Intestine of a transported animal showing a moderate NT-immunostaining in the cytoplasm of enterocytes lining the epithelium (Ep). (D) Gills of a transported animal showing NT-immunostaining in the epithelial cells lining both filaments (F) and lamellae (arrows). (E) Gills of an animal from the stressed group showing 8-OHdG immunopositive nuclei in the epithelial cells lining both filaments and lamellae. Control animal (insert in (E)) shows a similar positivity. (F) 8-OHdG immunopositive nuclei in the epithelial cells lining the intestinal mucosa. Scale bars: (A-F) $20 \mu \mathrm{M}$, insert in (E) $20 \mu \mathrm{M}$.

Immunopositivity to 8-OHdG antibody was detected in the nuclei of: (i) epithelial cells of skin; (ii) epithelial cells lining the gastric mucosa; (iii) epithelial cells lining both filaments and lamellae of gills (Figure 5E, insert in (E)); (ii) enterocytes of the intestinal 
mucosa (Figure 5F); (iii) hepatocytes of liver parenchyma. No differences in terms of immunoreactivity were detected between controls and stressed animals (Table 2).

\section{Discussion}

Live fish transport is considered an essential procedure in aquaculture, but often exposes fish to stressors such as air exposure, handling, crowding and confinement [3,24,25]. Furthermore, it is known to cause the deterioration of transport-water conditions, reducing dissolved oxygen levels and $\mathrm{pH}$ and increasing ammonia nitrogen concentrations [26,27]. In fact, fish swimming activity during transportation period may lead to an increase in both respiration rate and nitrogenous waste [28], resulting in dissolved oxygen consumption and carbon dioxide as well as ammonia excretion in the water.

Fish react to stress by raising the levels of catecholamines and glucocorticoids such as cortisol hormone which is considered a primary stress indicator [29]. Increases in cortisol levels due to transport stress have already been described in both freshwater and marine species such as channel catfish (Ictalurus punctatus) [26,27] and Pacific bluefin tuna (Thunnus orientalis) [30]. Differently, in the present study, muscle cortisol levels significantly rose immediately after fish were loaded on the truck, indicating an increased stress level during the loading practice prior to the transport itself. In fact, after $16 \mathrm{~h}$ from departure, fish started to gradually recover, as attested by a significant decrease in cortisol level, but did not return to the basal values. A similar cortisol trend has been recently found by Wu et al. [31] in the tiger grouper serum (Epinephelus fuscoguttatus) during a simulated transport. This result possibly indicates that if, on one hand, meagre are able to rapidly face stress conditions associated with transport, on the other, it suggests that this stress response could be primarily associated to animals' condition at departure, in terms of manipulation, net confinement and air exposure, or to the transport operator's skills during loading, rather than to the transport itself.

It is worth noting that the cortisol trend observed in this study is well reflected by the molecular results. In fact, Real-Time PCR analysis evidenced that the highest expression of glucocorticoid receptor gene was detected in muscle of animals just after loading on the truck, whereas a decreasing trend of expression was observed during and after transport, returning to control levels immediately after transfer. These results confirm that the strong affinity between cortisol and the intracellular glucocorticoid receptor led to an increase in the GR mRNA levels [32,33].

Iwama et al. [34] reported that at the cellular level, the response of fish to stressors involves an increased synthesis of heat shock proteins. In particular, HSP70 expression has been observed in several fish species after exposure to various stress conditions $[19,20,27,35-49]$. In the present work, immunoreactivity to HSP70 antibody was detected in several tissues and organs although no differences were found between control and stressed animals. In a previous study, an increased expression of inducible HSP70 mRNA in larvae and fry of sea bass (Dicentrarchus labrax) subjected to transport stress as well as in skin and muscle of adults exposed to the same stress condition was demonstrated [19]. In the same work, Poltronieri et al. [19] evidenced that the presence of HSP70 protein was detectable only in skeletal muscle of transported animals. The immunohistochemical localization of HSP70 protein has been also demonstrated in the epithelia of renal tubules, gills and skin of carp (Cyprinus carpio) subjected to transport stress, whereas in trout (Oncorhynchus mykiss), HSP70 protein has been immunohistochemically detected only in red skeletal muscle and epidermis of control animals [20]. Recently, Refaey and Li [27] demonstrated that transported catfish exhibited a significantly higher level in the mRNA expressions of both hepatic HSP70 and HSP90 suggesting that the increment in HSPs may reflect the improved ability of channel catfish to adapt to transport stress.

During oxidative stress conditions, lipid peroxidation, protein carbonyl formation and DNA damage occur because more ROS are generated than cells can remove [12]. Lipid peroxides are unstable indicators of oxidative stress in cells that decompose to form more complex and reactive compounds such as 4-hydroxynonenal (HNE), which represents a 
natural by-product of lipid peroxidation [16]. In the experimental conditions used in this study, the anti-HNE antibody revealed positive immunostaining in the oropharyngeal cavity, stomach, liver, intestine, and skin, although no differences were detectable between control and transported animals. In a previous study, immunohistochemistry was used to investigate HNE cellular localization, showing that immunopositivity was mainly localized in melanomacrophage centers of kidney, liver, spleen, and ovary of the grass goby Zosterisessor ophiocephalus sampled in different areas of the Venice Lagoon, whereas animals from the detoxified control group did not exhibit any immunopositivity [23]. Recently, Fiocchi et al. [50] detected an increased HNE immunopositivity in several tissues of sea bass (Dicentrarchus labrax) subjected to handling and temperature increase.

In this work, nitrotyrosine (NT) as a marker for peroxynitrite production has been investigated by immunohistochemistry revealing the presence of the protein in various tissues of both transported and control animals. Moreover, the immunostaining intensity observed in skin and gills of transported animals was higher than that observed in controls. It is worth noting that increasing ammonia levels is considered one of the main fish stress inducers $[28,51]$. Therefore, the higher NT immunostaining intensity observed in this study could also be ascribed to the worsening of water quality parameters, as already reported in gilthead seabream juveniles exposed to ammonia changes [49]. In the grass goby Zosterisessor ophiocephalus sampled in different areas of the Venice Lagoon, the immunohistochemical localization of NT was detectable in melanomacrophage centers of spleen, kidney, liver and ovary, whereas animals from the detoxified control group did not exhibit any immunopositivity [23]. An increased NT immunopositivity has been recently observed in several tissues of sea bass (Dicentrarchus labrax) subjected to handling and temperature if compared to control animals [50].

An example of DNA damage due to bases' modification is represented by the oxidation of deoxyguanosine to form 8-hydroxy-2'-deoxyguanosine (8-OHdG) [17]. In the present work, immunopositivity to 8-OHdG antibody was detected in the nuclei of several tissues although no differences in term of immunoreactivity was detected between controls and stressed animals. In a previous work, 8-OHdG expression and localization was investigated in the grass goby Z. ophiocephalus, collected in two sites of the Venice lagoon (Porto Marghera and Caroman) with different levels of pollution [52]. In particular, authors observed that in liver of males from Porto Marghera, the most polluted area, 8-OHdG expression was significantly greater than that observed in females, whereas animals from Caroman showed no sex-related differences. Changes in 8-OHdG activity as a product of oxidative DNA damage, histopathological changes and antioxidant responses have been recently investigated in rainbow trout exposed to linuron, a commonly used herbicide. Indeed, immunopositivity to 8-OHdG was detected both in liver and gill tissues of the treated animals, proving that an increase of tissue 8-OHdG, a well-known product of oxidative DNA damage, may be a consequence of oxidative stress [53].

\section{Conclusions}

In the present study, the teleost meagre Argyrosomus regius exposed to a $48 \mathrm{~h}$ transport clearly exhibited a stress response confirmed by marked changes in muscle cortisol and $g^{r}$ gene expression levels after loading, prior to the beginning of the transport. However, already after $16 \mathrm{~h}$, a decreasing trend in the same stress indicators has been observed with a return of $g r$ expression to the control levels still during transport, suggesting that this species is able to adapt rather quickly to these stress conditions. A strong NT immunopositivity was detected in epithelial cells of skin and gills of transported fish, likely due to deterioration in the water quality parameters during the transportation. Transport of live fish is an unavoidable practice in the aquaculture industry and thus it represents a critical welfare issue. Although research on welfare and morpho-physiological response to stressors of farmed fish species has begun to take hold in recent years, further studies are still needed in order to ensure better management of fish commercial transport, preserving animal health and welfare. 
Author Contributions: Conceptualization, G.R. and D.B.; methodology, M.B., L.M., S.C., G.R. and D.B.; cortisol analysis, M.B. and D.B.; molecular biology analysis, M.B. and L.M.; immunohistochemical analysis, M.B. and G.R.; writing-original draft preparation, M.B., G.R. and D.B.; funding acquisition, G.R. and D.B. All authors have read and agreed to the published version of the manuscript.

Funding: This research was funded by project Fondi di Ateneo to Daniela Bertotto and Giuseppe Radaelli.

Institutional Review Board Statement: The study was conducted according to the principles stated by the Regulation (EC) no. 1/2005 on the protection of animals during transport and by the Directive (EC) $86 / 609 / \mathrm{EEC}$ on the protection of animals used for experimental and other scientific purposes.

Data Availability Statement: The data presented in this study are available within the article.

Acknowledgments: The authors wish to thank Elena Negrato, Giovanni Caporale, Carlo Poltronieri and the students Federico Leva and Michele Boscolo Papo for their technical assistance.

Conflicts of Interest: The authors declare no conflict of interest. The funders had no role in the design of the study; in the collection, analyses, or interpretation of data; in the writing of the manuscript, or in the decision to publish the results.

\section{References}

1. Spezzani, C.; Ruffo, G.; Fabris, A.; Mordenti, O.; Manfrin, A.; Salati, F.; Giorietto, F.; Salogni, C. Manuale per la Gestione del Controllo del Benessere dei Pesci Durante il Trasporto su Strada; Italian Ministry of Health: Rome, Italy, 2018; pp. 1-59.

2. EFSA (European Food Safety Authority). Opinion of the scientific panel for animal health and welfare on a request from the commission related to the welfare of animals during transport. EFSA J. 2004, 2, 1-36. [CrossRef]

3. OIE (World Health Animal Organization). Welfare of Farmed Fish during Transport. OIE Aquatic Animal Health Code, 2nd ed.; World organization for animal health: Paris, France, 2015; pp. 1-4.

4. Kino, T.; Chrousos, G.P. Glucocorticoid and mineralocorticoid receptors and associated diseases. Essays Biochem. 2004, 40, 137-155. [CrossRef] [PubMed]

5. Palstra, A.P.; Mendez, S.; Dirks, R.P.; Schaaf, M.J.M. Cortisol Acting Through the Glucocorticoid Receptor Is Not Involved in Exercise-Enhanced Growth, But Does Affect the White Skeletal Muscle Transcriptome in Zebrafish (Danio rerio). Front. Physiol. 2019, 9, 1-11. [CrossRef] [PubMed]

6. Sadoel, B.; Vijayan, M.M. Stress and growth. In Biology of Stress in Fish, 2nd ed.; Schreck, C.B., Tort, L., Farrell, A.P., Brauner, C.J., Eds.; Elsevier: London, UK, 2016; Volume 35, pp. 167-205. [CrossRef]

7. Kuo, T.; Harris, C.A.; Wang, J.C. Metabolic functions of glucocorticoid receptor in skeletal muscle. Mol. Cell. Endocrinol. 2013, 380, 79-88. [CrossRef] [PubMed]

8. Benítez-Dorta, V.; Caballero, M.J.; Izquierdo, M.; Manchado, M.; Infante, C.; Zamorano, M.J.; Montero, D. Total substitution of fish oil by vegetable oils in Senegalese sole (Solea senegalensis) diets: Effects on fish performance, biochemical composition, and expression of some glucocorticoid receptor-related genes. Fish. Physiol. Biochem. 2013, 39, 335-349. [CrossRef]

9. Mommsen, T.P.; Vijayan, M.M.; Moon, T.W. Cortisol in teleosts: Dynamics, mechanisms of action, and metabolic regulation. Rev. Fish Biol. Fish. 1999, 9, 211-268. [CrossRef]

10. Schreck, C.B. Stress and compensation in teleostean fishes: Response to social and physical factors. In Stress and Fish; Pickering, A.D., Ed.; Academic Press: London, UK, 1981; pp. 295-321.

11. Wendelaar Bonga, S.E. The stress response in fish. Physiol. Rev. 1997, 77, 591-625. [CrossRef] [PubMed]

12. Halliwell, B.; Gutteridge, J.M.C. Free Radicals in Biology and Medicine, 3rd ed.; Oxford University Press: Oxford, UK, 1999; pp. 1-905. [CrossRef]

13. Davies, K.J.A. Oxidative stress, the paradox of aerobic life. In Free Radical and Oxidative Stress: Environment, Drugs and Food Additives, 2nd ed.; Rice Evans, C., Halliwell, B., Land, G.G., Eds.; Portland Press: London, UK, 1995; Volume 40, pp. 1-31.

14. Winston, G.W.; Di Giulio, R.T. Prooxidant and antioxidant mechanisms in aquatic organisms. Aquat. Toxicol. 1991, 19, 137-161. [CrossRef]

15. Ischiropoulos, H.; Zhu, L.; Chen, J.; Tsai, M.; Martin, J.C.; Smith, C.D.; Beckman, J.S. Peroxynitrite-mediated tyrosine nitration catalyzed by superoxide dismutase. Arch. Biochem. Biophys. 2002, 298, 431-437. [CrossRef]

16. Aldini, G.; Dalle-donne, I.; Facino, R.M.; Milzani, A.; Carini, M. Intervention Strategies to Inhibit Protein Carbonylation by Reactive Carbonyls. Med. Res. Rev. 2006, 27, 817-868. [CrossRef]

17. Ploch, S.A.; Lee, Y.; MacLean, E.; Di Giulio, R.T. Oxidative stress in liver of brown bullhead and channel catfish following exposure to tert-butyl hydroperoxide. Aquat. Toxicol. 1999, 46, 231-240. [CrossRef]

18. Pilger, A.; Rüdiger, H.W. 8-Hydroxy-2'-deoxyguanosine as a marker of oxidative DNA damage related to occupational and environmental exposure. Int. Arch. Occup. Environ. Health 2006, 80, 1-15. [CrossRef] 
19. Poltronieri, C.; Maccatrozzo, L.; Simontacchi, C.; Bertotto, D.; Funkenstein, B.; Patruno, M.; Radaelli, G. Quantitative RT-PCR analysis and immunohistochemical localization of HSP70 in sea bass Dicentrarchus labrax exposed to transport stress. Eur. J. Histochem. 2007, 51, 125-136. [CrossRef]

20. Poltronieri, C.; Negrato, E.; Bertotto, D.; Majolini, D.; Simontacchi, C.; Radaelli, G. Immunohistochemical localization of constitutive and inducible Heat Shock Protein 70 in carp (Cyprinus carpio) and trout (Oncorhynchus mykiss) exposed to transport stress. Eur. J. Histochem. 2008, 52, 191-198. [CrossRef]

21. Bertotto, D.; Poltronieri, C.; Negrato, E.; Majolini, D.; Radaelli, G.; Simontacchi, C. Alternative matrices for cortisol measurement in fish. Aquac. Res. 2010, 41, 1261-1267. [CrossRef]

22. Bertotto, D.; Poltronieri, C.; Negrato, E.; Richard, J.; Pascoli, F.; Simontacchi, C.; Radaelli, G. Whole body cortisol and expression of HSP70, IGF-I and MSTN in early development of sea bass subjected to heat shock. Gen Comp Endocrinol. 2011, 174, 44-50. [CrossRef] [PubMed]

23. Pascoli, F.; Negrato, E.; Di Giancamillo, A.; Bertotto, D.; Domeneghini, C.; Simontacchi, C.; Mutinelli, F.; Radaelli, G. Evaluation of oxidative stress biomarkers in Zosterisessor ophiocephalus from the Venice Lagoon, Italy. Aquat. Toxicol. 2011, 101, 512-520. [CrossRef] [PubMed]

24. Sandodden, R.; Findstad, B.; Iversen, M. Transport stress in Atlantic salmon (Salmo salar L.): Anaesthesia and recovery. Aquac. Res. 2001, 32, 87-90. [CrossRef]

25. Chandroo, K.P.; Cooke, S.J.; Mckinley, R.S.; Moccia, R.D. Use of electromyogram telemetry to assess the behavioural and energetic responses of rainbow trout, Oncorhynchus mykiss (Walbaum) to transportation stress. Aquac. Res. 2005, 36, 1226-1238. [CrossRef]

26. Refaey, M.M.; Tian, X.; Tang, R.; Li, D. Changes in physiological responses, muscular composition and flesh quality of channel catfish Ictalurus punctatus suffering from transport stress. Aquaculture 2017, 478, 9-15. [CrossRef]

27. Refaey, M.M.; Li, D. Transport stress changes blood biochemistry, antioxidant defense system, and hepatic HSPs mRNA expressions of channel catfish Ictalurus punctatus. Front. Physiol. 2018, 9, 1-11. [CrossRef]

28. Paterson, B.D.; Rimmer, M.A.; Keike, G.M.; Semmens, G.I. Physiological responses of the Asian sea bass, Lates calcarifer to water quality deterioration during simulated live transport: Acidosis, red-cell swelling, and levels of ions and ammonia in the plasma. Aquaculture 2003, 218, 717-728. [CrossRef]

29. Barton, B.A.; Iwama, G.K. Physiological changes in fish from stress in aquaculture with emphasis on the response and effects of corticosteroids. Annu. Rev. Fish Dis. 1991, 1, 3-26. [CrossRef]

30. Honryo, T.; Oakada, T.; Kawahara, M.; Kurata, M.; Agawa, Y.; Sawada, Y.; Miyashita, S.; Takii, K.; Ishibashi, Y. Estimated time for recovery from transportation stress and starvation in juvenile Pacific bluefin tuna Thunnus orientalis. Aquaculture 2018, 484, 175-183. [CrossRef]

31. Wu, B.; Wang, Q.; Cao, J.; Mei, J.; Xie, J. Effects of ascorbic acid and $\beta$-1,3-glucan on survival, physiological response and flesh quality of cultured tiger grouper (Epinephelus fuscoguttatus) during simulated transport in water. Biology 2020, 9, 37. [CrossRef]

32. Aluru, N.; Vijayan, M.M. Hepatic transcriptome response to glucocorticoid receptor activation in rainbow trout. Physiol. Genom. 2007, 31, 483-491. [CrossRef]

33. Faught, E.; Vijayan, M.M. Mechanisms of cortisol action in fish hepatocytes. Comp. Biochem. Physiol. B Biochem. Mol. Biol. 2016, 199, 136-145. [CrossRef] [PubMed]

34. Iwama, G.K.; Thomas, P.T.; Forsyth, R.B.; Vijayan, M.M. Heat shock protein expression in fish. Rev. Fish Biol. Fish. 1998, 8, 35-56. [CrossRef]

35. Sanders, B.M.; Nguyen, J.; Martin, L.S.; Howe, S.R.; Coventry, S. Induction and subcellular localization of two major stress proteins in response to copper in the fathead minnow Pimephales promelas. Comp. Biochem. Physiol. C. 1995, 112, 335-343. [CrossRef]

36. Williams, J.H.; Farag, A.M.; Stansbury, M.A.; Young, P.A.; Bergman, H.L.; Petersen, N.S. Accumulation of HSP70 in juvenile and adult rainbow trout gill exposed to metal-contaminated water and/or diet. Environ. Toxicol. Chem. 1996, 15, 1324-1328. [CrossRef]

37. Vijayan, M.M.; Pereira, C.; Forsyth, R.B.; Kennedy, C.J.; Ywama, G.K. Handling stress does not affect the expression of hepatic heat shock protein 70 and conjugation heat-shock-cognate HSC71 gene from rainbow trout. Eur. J Biochem. 1997, 204, 893-900.

38. Vijayan, M.M.; Pereira, C.; Kruzynski, G.; Ywama, G.K. Sublethal concentrations of contaminant induce the expression of hepatic heat shock protein 70 in two salmonids. Aquat. Toxicol. 1998, 40, 101-108. [CrossRef]

39. Schmidt, H.; Posthaus, H.; Busato, A.; Wahli, T.; Meier, W.; Burkhardt-Holm, P. Transient increase in chloride cell number and heat shock protein expression (hsp70) in brown trout (Salmo trutta fario) exposed to sudden temperature elevation. Biol. Chem. 1998, 379, 1227-1233. [CrossRef]

40. Duffy, L.K.; Scofield, E.; Rodgers, T.; Patton, M.; Bowyer, R.T. Comparative baseline levels of mercury, HSP70 and HSP60 in subsistence fish from the Yukon-Kuskokwim delta region of Alaska. Comp. Biochem. Physiol. C Pharmacol. Toxicol. Endocrinol. 1999, 124, 181-186. [CrossRef]

41. Hassanein, H.M.A.; Banhawy, M.A.; Soliman, F.M.; Abdel-Rehim, S.A.; Muller, W.E.G.; Schroder, H.C. Induction of HSP70 by the herbicide oxyfluoren (goal) in the Egyptian Nile fish, Oreochromis niloticus. Arch. Env. Contain. Toxicol. 1999, 37, 78-84. [CrossRef]

42. Currie, S.; Moyes, C.D.; Tufts, B.L. The effects of heat shock and acclimatation temperature on hsp70 and hsp30 mRNA expression in rainbow trout: In vivo and in vitro comparisons. J. Fish Biol. 2000, 56, 398-408. [CrossRef]

43. Ali, K.S.; Dorgai, L.; Ábrahám, M.; Hermesz, E. Tissue- and stressor-specific differential expression of two hsc70 genes in carp. Biochem. Biophys. Res. Commun. 2003, 307, 503-509. [CrossRef] 
44. Ali, K.S.; Dorgai, L.; Gazdag, A.; Ábrahám, M.; Hermesz, E. Identification and induction of hsp70 gene by heat shock and cadmium exposure in carp. Acta Biol. Hung. 2003, 54, 323-334. [CrossRef]

45. Zarate, J.; Bradley, T.M. Heat shock proteins are not sensitive indicators of hatchery stress in salmon. Aquaculture 2003, 223, 175-187. [CrossRef]

46. Gornati, R.; Papis, E.; Rimoldi, S.; Terova, G.; Saroglia, M.; Bernardini, G. Rearing density influences the expression of stress-related genes in sea bass (Dicentrarchus labrax L). Gene 2004, 341, 111-118. [CrossRef]

47. Deane, E.E.; Woo, N.Y. Cloning and characterization of the hsp70 multigene family from silver sea bream: Modulated gene expression between warm and cold temperature acclimatation. Biochem. Biophys. Res Commun. 2005, 330, 776-783. [CrossRef]

48. Ojima, N.; Yamashita, M.; Watabe, S. Comparative expression analysis of two paralogous Hsp70s in rainbow trout cells exposed to heat stress. Biochim. Biophys. Acta 2005, 1681, 99-106. [CrossRef]

49. Zarantoniello, M.; Bortoletti, M.; Olivotto, I.; Ratti, S.; Poltronieri, C.; Negrato, E.; Caberlotto, S.; Radaelli, G.; Bertotto, D. Salinity, Temperature and Ammonia Acute Stress Response in Seabream (Sparus aurata) Juveniles: A Multidisciplinary Study. Animals 2021, 11, 97. [CrossRef] [PubMed]

50. Fiocchi, E.; Civettini, M.; Carbonara, P.; Zupa, W.; Lembo, G.; Manfrin, A. Development of molecular and histological methods to evaluate stress oxidative biomarkers in sea bass (Dicentrarchus labrax). Fish Physiol. Biochem. 2020, 46, 1577-1588. [CrossRef] [PubMed]

51. Eissa, N.; Wang, H.P. Transcriptional stress responses to environmental and husbandry stressors in aquaculture species. Rev. Aquac. 2016, 8, 61-88. [CrossRef]

52. Negrato, E.; Vascellari, M.; Capolongo, F.; Binato, G.; Da Dalt, L.; Papo, M.B.; Gioacchini, G.; Carnevali, O.; Bertotto, D.; Radaelli, G. Expression of 8-OHdG in Zosterisessor ophiocephalus from the Venetian lagoon, Italy. Eur. J. Histochem. 2013, 57, 46-53. [CrossRef]

53. Topal, A.; Gergit, A.; Özkaraca, M. Assessment of oxidative DNA damage, oxidative stress responses and histopathological alterations in gill and liver tissues of Oncorhynchus mykiss treated with linuron. Hum. Exp. Toxicol. 2020, 20, 1-10. [CrossRef] 